\title{
On the Amendment and Perfection of Legislation of Mortgage
}

\author{
Guohua She \\ Hunan University of Science and Engineering \\ Yongzhou 425100, Hunan, China \\ E-mail:pcx550@163.com
}

\begin{abstract}
Among all real rights granted by way of security, mortgage, as the "King of Guarantee" has the special advantage. The Guarantee Law of the People's Republic of China had nothing to start with. Since the application of the Guarantee Law of the PRC ten years ago, the author offers suggestions for perfecting the legislation of mortgage law of China from six aspects, namely setting up legal mortgage, subdividing and perfecting the mortgage of rights, distinguishing the combined mortgage and the common mortgage, creating the mortgage of securities and the mortgage of owners, constituting new consortium mortgage and floating mortgage, and forming the ship mortgage.
\end{abstract}

Keywords: Mortgage, Guaranty, Legislation, Countermeasure

At the time with prosperous market economy, to maintain the speed and the safety of transactions is the essential task of civil and commercial law. The responsibility of maintaining the safety of transactions and decreasing the risks of transactions falls in the guarantee system. The mortgage-guarantee system is originated from ancient Greek. At the late Roman Empire, the Roman private law has been introduced and gained complete development, which has turned into the most popular guarantee mode (Kunlin Zhao, 1998, p65). Under the imitation of other countries, the mortgage gains more attentions. Especially along with the development of modern market economy, its types and applications have been extended. The continental legal system differentiates the pledge and the mortgage. It adopts three standards to differentiate the two. The first standard is about whether transfer the possession of property or not. For example, the French Code Civil regulates that the mortgage is the real right of fixed assets for the sake of paying off debts. It is sorted into the legal mortgage, the judgment mortgage, and the agreement mortgage. The pledge includes the chattel pledge and the pledge of immovables. Japan Civil Code takes the transfer as the standard. Transferring the possession of property is the pledge, and if not, the mortgage. The second is to take the transfer and the nature of property as the standard. For example, German Civil Code regulates that for the immovables, there is only mortgage. And the mortgage does not transfer the possession of immovables. The pledge is to transfer the possession of property. The third is to take the nature of property as the standard. For example, German Civil Code regulates that the mortgage is for the immovables in guarantee and the pledge is for the movables, not matter whether transferring the possession or not. In contrast, the Anglo-American law system does not distinguish the pledge and the mortgage clearly. It lays stresses on mortgage. The Anglo-American law system divides the mortgage into the mortgage in common law and the mortgage in equity law. In practice, any property can be used for the corpore of mortgage. Conditions in America are similar to that in British. In ancient China, the pledge and the mortgage are mixed together in practice. There is not a strict difference between them in law. The civil and commercial law starts later in China. Till the Third Plenary Session of the $11^{\text {th }}$ Central Committee, it steps into the fast development way. In 1995, China issues the Guarantee Law of the People's Republic of China (Guarantee Law for short), which establishes the standard of distinguishing the mortgage and the pledge.

The Guarantee Law especially regulates the mortgage system in Chapter 3 by 30 Articles. It is the most complete regulations concerning the mortgage in China. Since the issue of the Guarantee Law, it has exerted a positive effect on constituting a legal system for China's market economy and maintaining trading safety and market order. However, along with the deepening of social practice and judicial practice, some defects of the Guarantee Law are displayed. At the transmission of social and market economy in China, it is urgent to further perfect the legislation of mortgage.

\section{Establish the legal mortgage}

The legal mortgage happens directly based on laws. "This mortgage has the validity of law without register. It is valid at the day when conditions happen. (Kunlin Zhao, 1998, p73)"

On principle the mortgage is the agreed real rights granted by way of security. It is contracted by parties. Laws also regulate that the mortgage appears naturally as there is certain relation according to the needs of some relations instead of agreements of parties. It is the essential difference between legal mortgage and common mortgage. Take French Civil Code for example. The legal mortgage includes: the wife has the legal mortgage right to husband's property; the ward has the legal mortgage right to guardian's property; the state, public community, and state-operated enterprise have the 
legal mortgage right to receiving teller and accountant's property; creditors have the legal mortgage right to debtors' property; tax authority has the legal mortgage right to tax payers' property; the exchequer has the legal mortgage right to special taxation for the sake of insuring the success of wars. The legal mortgage right happens due to laws' Articles. The special rules in laws will enjoy the priority in practice. If there are no special rules, relevant regulations on common mortgage right are effective. Besides the legal mortgage right, there is a judgment mortgage, which happens due to the judgment of court. In modern time, in order to guaranteeing the trading safety, many countries set strict limits on legal mortgage. For example, German laws recognize the legal mortgage right to the debts generated from construction contracts. Japanese laws replace legal mortgage system with first-get priority system and unmovable pledge right. Only France recognizes the legal mortgage right to a wider scope and regulates the judgment mortgage right. According to the Guarantee Law of China, there is no legal mortgage right or judgment mortgage right. The agreed mortgage right is dominating. Compared with former review, the defects are clear. Considering China's conditions and referencing from the widely-accepted principles in legislation, China can establish these kinds of legal mortgage rights: the ward has the legal mortgage right to guardian's property; creditors have the legal mortgage right to debtors' bankruptcy property; the tax authority has the legal mortgage right to tax payers' all property.

\section{Subdivide and perfect the right mortgage}

The right mortgage is a real right granted by way of security that takes the usufructuary right as the object. Viewing from other countries' laws, the rights that can be taken as the object of mortgage are mainly traditional civil superficies (ground usufruct, emphyteusis, and usufruct of farm land). Taiwan province regulates that: the pawning right can also be used as the object of mortgage. Special laws, such as Mining Law, Fishing Law, and Forest Law, in Japan and European countries and American countries, regulate that these non-land usufructs, such as mining right, fishing right, and forest right, can also be taken as objects of mortgage, forming semi- mortgage (Ichiro Kato \& Liangping Lin, ?, p155). Similar to Japan, most countries regulate the right mortgage. The object of semi-mortgage is limited to the usufruct of immovables. For example, Japanese Civil Law regulates that the object of right mortgage is limited to superficies and emphyteusis (Ichiro Kato \& Liangping Lin, ?, p155). In Taiwan province, parties can set up mortgage rights based on the usufruct of superficies and emphyteusis and the semi-usufruct of mining right, pawning right, and fishing right. Article 47 in The PRC Administration of Urban Real Property Development Tentative Procedures and Article 34 in the Guarantee Law of PRC respectively regulates: Article 34 The state-owned right to the use of land, house and other land fixtures which the mortgagor is entitled to dispose of pursuant to the law and the right to the use of land on the un-reclaimed land such as un-reclaimed mountains, un-reclaimed valleys, unclaimed hills or un-reclaimed beaches which is contracted for management by the mortgagor in accordance with law and is agreed to mortgage by the contractee can be mortgaged. Therefore, in China the mortgage rights merely include the right to the use of land, which can be taken as the mortgage directly (Wusheng Xu, 1999, p393).

However, China's present legislation of mortgage has no relevant regulations. Both present civil and commercial laws and special Guarantee Law do not regulate the usufructuary right. At present, the contracted land in rural areas is mainly operated and defined by contracts. Some usufructuary rights are merely discussed and concerned in legal papers but not clear legal regulations. Some semi-usufructuary rights, such as the mining right, fishing right, and water breeding right, can not be mortgaged because they are not allowed to be transferred. It is an inevitable tendency to establishing the usufructuary right. Therefore, it is necessary to subdivide and perfect the right mortgage in Guarantee Law.

\section{Differentiate the combined mortgage and the common mortgage}

The common mortgage is in contrast to the single mortgage. The single mortgage is only for certain special property. The common mortgage is based on several different properties. The meanings for differentiating the single mortgage and the common mortgage are: as the gages include several different properties, the mortgagee has the mortgage right. The mutual relations of several properties should be dealt with properly. Otherwise, it will hurt others' interests, whose interests relate with the common gages. The common mortgage is based on parties' contracts that agree to take several properties as the mortgage. In another condition, the common mortgage happens because of the separation of gages after the mortgage. The common mortgage has been widely accepted by most countries. According to the contents of the Guarantee Law, mortgagor can mortgage all kinds of properties together. Here the so-called combined mortgage includes the common mortgage in nature. As for the nature of common mortgage, there are single mortgage, complex mortgage, and compromise mortgage theoretically. According to the theory of single mortgage, the common mortgage only has one mortgage right. Several properties serve as the object of one mortgage right together. Taiwan's famous scholars Youchang Huang in his Explanations for Civil Law's Real Right and Jie Cao in his On China's Civil Law's Real Rights adopt the theory of complex mortgage. According to the theory of complex mortgage, the common mortgage is the collection of several mortgage rights based on several properties. Therefore, it can be named as the general mortgage. Taiwan scholars Shangkuan Shi, Zhaowei Li, and Zaiquan Xie hold this idea. The theory of compromise mortgage agrees that the common mortgage can be single mortgage or complex mortgage. What it is the single mortgage or the complex mortgage is based on practical conditions. Taiwan scholar Yubo Zheng is insisted on the 
theory of compromise mortgage. He thinks that the common mortgage can be the single mortgage or the complex mortgage. The same mortgagor mortgages his or her gages, what is the single mortgage. In order to mortgage for the same debt, several properties turn into gages, what is the complex mortgage (Mingyue Xu, 1998, p102). In order to maintain the coherence of laws and reduce unnecessary conflicts and juridical mistakes, we should discard the concept of "combined mortgage" and adopt the single mortgage and the common mortgage that are widely accepted by the world.

\section{Create the security mortgage and the owner mortgage}

The so-called security mortgage is set up by the land owner. Based on the application of land owner, for the sake of self or others' fulfillment of debts, the register administration gives the mortgaged security to the creditor. As the debtor does not fulfill the debt, the holder of mortgaged security can exercise the mortgage right by presenting the mortgaged security. According to German laws, the mortgage right of mortgaged security has the public power. In Japan, the so-called mortgaged security is far different from Switzerland Civil Law. Japanese mortgaged security combines the creditor's right and the mortgage right together. The guaranteed debt and the mortgage right can not be separated from each other. They must be transferred at the same time. In German Civil Law and Switzerland Civil Law, the mortgaged security is pure representing mortgage right. The mortgage right represented by mortgaged security is separated from the creditor's right. Besides, according to the regulations of Japan Mortgage Security, the guaranteed corporate security with mortgage belongs to the scope of mortgaged security. In German laws, the mortgage right of security is the most common state of mortgage right. But the parties can mortgage for the creditor's right without the transfer of security in contracts. At this time, parties can register the mortgage right in relevant agency, forming the register mortgage right. As a matter of fact, the mortgage right of security should be registered in formation. But when it is to guarantee the creditor's right, it is not necessary to register. For a long period, China does not set put the mortgage right for security. Till Feb. 2000, China issues the Management Rules for Security Company's Stock Pledge Loan. It recognizes and regulates on the mortgage right of security, which creates a better condition for the amendment and the perfection of Guarantee Law.

The mortgage right of owner means the mortgage right enjoyed by the owner on his or her properties. It is also the mortgage right of the debtor. The common goal of mortgage right is the realization of guaranteed debt. Therefore, the mortgage right is usually possessed by other creditors. In France Law, as there are several mortgage rights over the same property, the mortgage right will disappear when the first mortgagee has been paid off. Then, the second mortgagee will get the mortgage right. Therefore, it usually does not recognize the mortgage of owner. The so-called mortgage right is usually the other-owner mortgage right. But in German law, the mortgage right follows the fixed order. As the No.1 mortgagee gets his or her payment, the mortgage right does not disappear. It will be transferred to the mortgagee, which can protect the interests of common creditors well. So the mortgage right is a back-forward owner mortgage right. Besides, the owner can also set up the mortgage right for his or her property or future debts. This mortgage right always belongs to the owner all the time. In nature, the land owner can issue his or her land mortgage security or register self as the mortgagee, which can help him or her enter the circulation field by taking the mortgage right as the investment. However, China's Guarantee Law has no relevant regulations on the mortgage right of owner. Apparently, it needs more regulations.

\section{Build new consortium mortgage right and floating mortgage right}

The consortium mortgage right is also named as the corporate mortgage right, which takes corporate properties, including the movables, immovables, and rights as the objects and sets up the mortgage right. It takes the corporation's total properties as the object of mortgage right. This special mortgage system appears for the needs of social and economic development, which is especially important for driving corporation's capital financing and exerting the multiple effects of corporate assets. There are no clear regulations on consortium mortgage in traditional civil laws, which is established gradually in practice. The consortium mortgage right takes the independent property as the object, completely in accordance with the mortgage right's requirements for values. Besides, in an economic meaning, the corporation is an independent economic body. Its property is a whole body in law, which forms the physical base for the corporation in business. If set up mortgages for part of properties, its general credit capability will be separated. Then, it can not get the giant capitals and the procedures are complex. If integrate corporate properties together, make its maximum value as the mortgage, namely setting up the consortium mortgage, the effect will be greatly improved.

The consortium mortgage right in continental legal system is originated from German railway consortium system. Later, it is developed by Japan. Viewing from legislation and practice, there are mainly three types of consortium: factory consortium mortgage right, mine consortium mortgage right, and public service consortium mortgage right. These consortium mortgage rights mean to get loans from banks by mortgaging the total property. The so-called total property includes movables, immovables, and rights based on necessary production. In law, the total property is taken as the fixed immovables. Therefore, in setting up the mortgage right, it should be specialized. Only taking some properties as the mortgage is not the consortium mortgage right. It is another mortgage right. Japan and Taiwan province regulate that 
the total property, as the object in consortium mortgage right, should not be separated or dealt with at random without the agreement of mortgagee. If the mortgagee agrees to divide or deal with the total property, the divided part should not be taken as the object of mortgage right.

In Anglo-America legal system, the floating mortgage right is similar to the consortium mortgage in the continental legal system. Differing from the consortium mortgage in continental legal system, the floating object is the total property of corporation at present and in future. It can not be specialized till the guaranty has been realized. Before the realization, the mortgagor can change the total property that is taken as the mortgage. There is certain floating. Therefore, the scope of object is wider. Even the corporate debt, though it is changeable, can serve as the object of guaranty together with other properties, and rights. The consortium mortgage in continental legal system is derived from German railway consortium system. It should be specialized at its formation. Therefore, it merely refers to the total property at present. It mainly includes the corporation's important movables, immovables, usufruct right, industrial property right, and leasehold of immovables. The changeable daily movables, future debts, commercial secrets, and business fame are excluded. In contrast, the floating mortgage in Anglo-America legal system sets loose requirements for the object of mortgage. It is more flexible and can reflect the needs for modern commercial economy and credit relations. However, it is only good for mortgagor (corporate debtor or the third party). It is not good for the creditor as the investor. Because the guaranteed base for credit is not sound. Therefore, both the continental legal system and the Anglo-American legal system have clear regulations on the consortium mortgage right or the floating mortgage right. China's Guarantee Law and other laws do not regulate these two mortgage rights. Some scholars agree that the "combined mortgage" in the Guarantee Law can be taken as the consortium mortgage (Wusheng Xu, 1999, p174-175). If apply the single mortgage to the common mortgage, the consortium mortgage should belong to one form of common mortgage. Then, the combined mortgage in China's present law is the common mortgage in nature. If adopt the complex mortgage, then the consortium mortgage does not belong to the common mortgage but one form of mortgage right. Then, the combined mortgage in China's Guarantee Law includes the common mortgage and the consortium mortgage in nature (Wusheng Xu, 1999, p174-175).Although it is reasonable, there are prominent defects and contradictions. As for whether construct the floating mortgage or not, more and more scholars hold a positive opinion (Zongle Huang, ?, p294). As a mater of fact, the floating mortgage and the consortium mortgage have their features, advantages, and disadvantages respectively. Viewing from the development of two systems, the floating mortgage means to overcome the defects of consortium mortgage and make the corporation get more capitals (Huabin Chen, ?, p654). Therefore, China can create the consortium mortgage and the floating mortgage at the same time. How to exercise the two in practice is determined by parties.

\section{Set up the ship mortgage right}

First of all, it is necessary to set up the ship mortgage right, which can nicely complement the defects of mortgage and pledge. As for whether the mortgage system in civil and commercial laws is right for ships, or, whether there is a ship mortgage system, there is not an established conclusion in the theoretical field and the practical field, what is caused by the fact that the ship mortgage is to take the special property ship as the object. The mortgage of immovables takes the immovables supplied by the debtor or the third party as the object, which does not transfer the possession of object. When the debtor does not perform the debt, the creditor shall be entitled to have right to keep the said property to offset the debt or have priority in satisfying his claim out of proceeds from the auction, sale of the said property. The immovables have large values in general. They are not easy to be moved, destroyed, or ruined. They are capable of guaranty by means of announcement and register. Because it does not transfer the possession, which does not affect others' usufructuary right, it can exert the exchange values and the utility values completely. As for the pledge of movables, when the debtor does not perform the debt, the creditor shall be entitled to have priority in satisfying his claim out of proceeds from the auction, sale of the said property. In civil law, the pledgee must transfer the possession of object. The pledgee should allow the pledgor to possess the object. Once the pledgee loses the possession of pledgings or returns the pledgings to the pledgor, the pledge disappears. The movable pledge system enables the pledgee possess the pledgings. On one hand, it can avoid the creditor to destroy the object, maintaining the value of the pledgings. On the other hand, it serves as a kind of psychological pressure on the debtor, driving him or her to pay off the debts in time. Once the debtor refuses to fulfill the debts, the pledgee can actualize the debt right directly, without worrying the debtor's delay. The pledge system is better for the creditor's interests.

However, no matter what it is the mortgage or the pledge, neither can satisfy the requirements of ships that are so important in shipping. The object of mortgage is limited to immovables, which is not based on the transfer of possession. The object of pledge is limited to movables, which is based on the transfer of possession. Then, no matter what we take the ship as the object of mortgage or the object of pledge is improper. On one hand, the main function of ship is to sail on the sea. Its movement does not hurt its exchange value. Therefore, it belongs to the movables and should not be taken as the object of mortgage. On the other hand, the ship, as a special material, has great exchange values and utility values. To exert the ship's utility value to a great degree depends on the management level of specialists. Once the ship, as the gage, is transferred to the creditor who is incapable of business management, the utility value of ship can not be 
exerted completely. Meanwhile, the specialized company that is good at ship management can not gain income to pay off the debts because of losing the possession to the ship. As a result, the repayment of debts loses the economic source. Therefore, to take the ship as the pledging is also improper. At least it is irrational in perspective of economy. As for the application of laws, we should reform the techniques of legislation and seek for the fairness (Guodong Xu, 1992, p137). The special status of commercial laws mainly focuses on these aspects: it amends and reforms individual articles in civil law, it makes special rules based on the common system of civil law, and it creates a special system that is not for the civil law (Junhai Liu \& Xinbao Zhang, 1997).

Secondly, we should actualize the integration and the connection of civil law legislation and commercial law legislation. For the sake of satisfying the needs for shipping, China's Maritime Law creates the special real right system, namely the ship mortgage system, based on the special conditions in shipping. Then, the ship, as the movable, can be mortgaged. The ship owner can register the mortgage of ship, but not transfer the possession of ship. By this way, the ship owner can realize the financing and hold the usufructuary right of ship. For the creditor, he or she can guarantee his or her creditor right and avoid the duty of maintaining the ship. The creation of ship mortgage system is a nice legislation indeed. However, "it is unknown for the real origin of ship mortgage. But we know that the Bottomry, in which the captain can mortgage the ship to the creditor, has been effective in Ancient Greek in $4^{\text {th }}$ century BC. The Bottomry has been identified in Roman law and later codes. But in $19^{\text {th }}$ century, because of the emergence of steel ship and the needs for more capitals, this financing mean seems to be improper. (William Tetley, 1985, p205)" At the very beginning of shipping trade, the Bottomry is popular in financing. But along with the continuous development of technologies, maritime shipping is not taken as the "ocean risk" any more. People begin to doubt the Bottomry. On the other hand, the financing subject will be unsatisfied as the large financing loans disappear due to the loss of ships. Therefore, the Bottomry has exited from the history stage gradually. Along with the construction and perfection of modern commercial banks' credit system, financial institutions (mainly commercial banks) aim at seeking for safe, reliable, and profitable investment market for their huge funds. Along with the development of technologies, to build or buy a ship needs a huge amount of capitals. In other words, without commercial banks' loans, ship companies can not collect necessary funds for building or buying ships. Under this circumstance, ship companies choose to sign "loan contracts" with financial institutions. By getting loans from financial institutions, these companies can build or buy new ships. At the same time, the two parties can sign a "ship mortgage contract" that makes the ship in construction or purchase turn into the gage that ensuring the fulfillment of the "loan contract". By this way, financial institutions get amounts of investment chances with guaranties. Ship companies get sufficient funds in operations. Therefore, the ship mortgage that takes ships as gages has been widely accepted and adopted more and more.

Secondly, the ship mortgage, as a legal system, has been adopted by more and more countries. In a sense, the aim of the Maritime Law regulating the ship mortgage system is to solve the financing issue of maritime shipping. Meanwhile, it offers legal insurance for commercial banks investing in shipping. As a matter of fact, the establishment of this system not only solves the difficult financing issue for shipping companies but also generate positive effects on developing countries enlarging domestic shipping business by foreign funds. Meanwhile, the establishment of ship mortgage system has a profound influence on driving the development of shipbuilding industry.

Today, along with the further development of ships, such as the size, the automation, the specialization, and the integration, ships have more values, not mention the guarantee effect of modern ships as guaranties. In order to integrate the ship mortgage system in different countries' maritime laws, many international agreements have been signed, which take the ship mortgage as the main content. Now the ship mortgage system has been adopted by most shipping countries. Therefore, as we amend the legislation of mortgage law, we should follow the trend and set up the ship mortgage right.

\section{References}

Chen, Huabin. (1998). Principles of Real Right Law. Beijing: China National School of Administration Press. p654.

Huang, Zongle. (1977). A study of floating guaranty ------ focusing on Scotland Law. National Taiwan University Law Review(vol.6). No.2. p294.

Ichiro Kato \& Lin, Liangping. (1985). the Guarantee Law(I). Tokyo: Community and Corporation Financial Business Research Association. p155.

Liu, Junhai \& Zhang, Xinbao. (1997). Review of commercial law studies. Law Research. No.1.

William Tetley. (1985).Maritime Liens and Claims. Business Law Communication Ltd, London. p205.

Xu, Guodong. (1992). Explanations for Principles of Civil Law. Beijing: China University of Political Science and Law Press. p137.

Xu, Mingyue. (1998). A Study of Guaranty Institution. Beijing: Law press. p102.

$\mathrm{Xu}$, Wusheng. (1999). Theories and Practices of Guaranty Law. Beijing: China Industrial and Commercial Press. p174-175, 393.

Zhao, Kunlin. (1998). Analysis of Mortgage Practice. Taiwan: Yongting Culture. p65, 73. 